\title{
Chiral oligomers by iterative tandem catalysis
}

\author{
Bart A.C. van As, ${ }^{\dagger}$ Jeroen van Buijtenen, ${ }^{\dagger}$ Andreas Heise, ${ }^{*}$ Quirinus B. Broxterman,${ }^{\S}$ \\ Gerard K.M. Verzijl, ${ }^{\S}$ Anja R.A. Palmans ${ }^{\dagger} *$ and E.W. Meijer ${ }^{\dagger}, *$ \\ ${ }^{\dagger}$ Laboratory of Macromolecular and Organic Chemistry, Eindhoven University of \\ Technology, PO Box 513, 5600 MB Eindhoven, The Netherlands. \\ ${ }^{ \pm}$DSM Research PM-CT, PO Box 18, 6160 MD Geleen, The Netherlands. \\ ${ }^{\S}$ DSM Research LS-ASC\&D, PO Box 18, 6160 MD Geleen, The Netherlands.
}

S-1. Synthetic procedures.

S-2. ${ }^{1} \mathrm{H}-\mathrm{NMR}$ spectra of ring-opening product $1 \mathrm{a}$ and 6-MeCL oligomeric species.

S-3. MALDI-TOF MS spectrum of 6-MeCL oligomers obtained in a one-pot system 


\section{S-1. Synthetic procedures}

\section{Materials}

6-methyl-e-caprolactone (6-MeCL) was synthesized by Baeyer-Villiger oxidation of 2-methylcyclohexanone following a reported procedure. ${ }^{1}(S)-6-\mathrm{MeCL}$ was synthesized by a double enzymatic ring-opening ring-closure procedure. ${ }^{2}$ Benzyl alcohol was purchased from Aldrich and distilled from $\mathrm{CaH}_{2}$ before use. Novozym 435 was purchased from Novozymes A/S. All solvents were stored on dry molecular sieves ( $3 \AA$ ) to remove traces of water. All other chemicals were purchased from Aldrich and used as received unless otherwise noted.

\section{Analytical methods}

${ }^{1} \mathrm{H}$ NMR spectra were measured in $\mathrm{CDCl}_{3}$ at 400,300 or $200 \mathrm{MHz}$ using a Varian Mercury Vx 400, 300 or 200 spectrometer. ${ }^{31} \mathrm{P}$ NMR spectra were measured in $\mathrm{CDCl}_{3}$ at 162 Mhz using a Varian Mercury Vx 400. Chiral gas chromatography (GC) was performed on a Shimadzu 6C-17A GC equipped with a Chrompack Chirasil-DEX CB $(\mathrm{DF}=0.25)$ column and an FID. Samples were injected using a Shimadzu AOC-20i autosampler. Injection and detection temperatures were set at $250{ }^{\circ} \mathrm{C}$ and separations were performed under isothermal conditions with the column temperature set at $125^{\circ} \mathrm{C}$, which afforded in all cases baseline separation of the enantiomers of 6-MeCL. Lactone conversions were determined by the internal standard method using 1,3,5-tri-tert-

\footnotetext{
${ }^{1}$ Trollsås, M.; Lee, V. Y.; Mecerreyes, D.; Loewenhielm, P.; Moeller, M.; Miller, R. D.; Hedrick, J. L., Macromolecules 2000, 33, 13, 4619.

${ }^{2}$ Manuscript in preparation.
} 
butylbenzene as the internal standard. The e.e.m was calculated as follows: e.e.m $=(\mathrm{R}-$ $\mathrm{S}) /(\mathrm{R}+\mathrm{S})$ where $\mathrm{R}$ and $\mathrm{S}$ represent the area of the $\mathrm{GC}$ peaks of the $(R)$ - and $(S)$ enantiomer, respectively. MALDI-TOF MS spectra were recorded on a PerSeptive Biosystems Voyager DE PRO spectrometer using a 50:50 mixture of $\alpha$-cyano-4hydroxycinnamic acid (CHCA) and trans-2-[3-(4-tert-Butylphenyl)-2-methyl-2propenylidene]malononitrile (DCTB) as a matrix.

\section{Enzymatic ring-opening of 6-MeCL}

Novozym $435(0.11 \mathrm{~g})$, benzyl alcohol $(0.27 \mathrm{~g} ; 2.5 \mathrm{mmol}), 6-\mathrm{MeCL}(1.3 \mathrm{~g} ; 10 \mathrm{mmol})$, 1,3,5-tri-tert-butylbenzene $(0.30 \mathrm{~g} ; 1.2 \mathrm{mmol})$, toluene $(2 \mathrm{~mL})$ and a magnetic stirring bar were added to a Schlenk tube. The mixture was stirred at room temperature for 1 hour. During reaction, samples $(\sim 0.02 \mathrm{~mL})$ were drawn from the reaction mixture using a glass Pasteur pipette. The sample was diluted with dichloromethane and the enzyme was removed from the sample by filtration over cotton wool. The samples were analyzed by chiral GC to determine the conversion of both enantiomers of 6-MeCL.

\section{Synthesis of 1 a using (rac)-6-MeCL}

Novozym $435(0.30 \mathrm{~g})$ and a magnetic stirring bar were added to a Schlenk tube. The tube was put overnight in a vacuum oven $(10 \mathrm{~mm} \mathrm{Hg})$ at $50{ }^{\circ} \mathrm{C}$ in presence of $\mathrm{P}_{2} \mathrm{O}_{5}$. The oven was backfilled with nitrogen and the tube was removed from the oven. Benzyl alcohol (1.3 g; $12 \mathrm{mmol}), 6-\mathrm{MeCL}(6.0 \mathrm{~g} ; 47 \mathrm{mmol}), 1,3,5$-tri-tert-butylbenzene (0.50 g; $2.0 \mathrm{mmol})$ and toluene $(7 \mathrm{~mL})$ were added to the tube. The mixture was stirred at room temperature for 9 hours. During reaction, samples $(\sim 0.02 \mathrm{~mL})$ were drawn from the 
reaction mixture using a glass Pasteur pipette. The sample was diluted with dichloromethane and the enzyme was removed from the sample by filtration over cotton wool. The samples were analyzed by chiral GC for conversion of BA and both enantiomers of 6-MeCL. At $90 \%$ BA conversion, the enzymatic reaction was stopped by filtration using a class 3 glass filter. The filtrate was concentrated and the remaining 6MeCL and BA were removed by distillation using a Kugelrohr apparatus $\left(\mathrm{T}=80{ }^{\circ} \mathrm{C}\right.$, $0.05 \mathrm{~mm} \mathrm{Hg})$. The product was used without further purification $(2.1 \mathrm{~g} ; 81 \%)$.

${ }^{1} \mathrm{H}$ NMR $\delta(\mathrm{ppm})$ 7.3-7.4 (m, Ar- $\left.H\right), 5.1\left(\mathrm{Ar}_{-} \mathrm{CH}_{2}-\mathrm{O}\right), 3.8\left(\mathrm{~m}, \mathrm{CH}\left(\mathrm{CH}_{3}\right) \mathrm{OH}\right), 2.4(\mathrm{~m}$, benzyl- $\left.\mathrm{CH}_{2}-\mathrm{OCOCH}_{2}\right), 1.65-1.35\left(\mathrm{~m}, \mathrm{OCOCH}_{2}\left(\mathrm{CH}_{2}\right)_{3}\right), 1.15\left(\mathrm{~d}, \mathrm{CH}_{3}\right)$

\section{Typical procedure for the addition of (rac)-6-MeCL to racemized 1}

Novozym $435(0.10 \mathrm{~g})$ was added to a $10 \mathrm{~mL}$ sample vial. The vial was put overnight in a vacuum oven $(10 \mathrm{~mm} \mathrm{Hg})$ at $50{ }^{\circ} \mathrm{C}$ in presence of $\mathrm{P}_{2} \mathrm{O}_{5}$. The oven was backfilled with nitrogen and the vial was removed from the oven. The racemized product 1 ( $1.3 \mathrm{~g}$; $5.6 \mathrm{mmol}), 6-\mathrm{MeCL}(3.0 \mathrm{~g} ; 24 \mathrm{mmol}), 1,3,5$-tri-tert-butylbenzene (0.47 g; $1.9 \mathrm{mmol})$, toluene $(4 \mathrm{~mL})$ and dry molecular sieves $(3 \AA)$ were added to a $50 \mathrm{~mL}$ round-bottom flask. The mixture was stirred at $45{ }^{\circ} \mathrm{C}$ for 16 hours to remove traces of water. The mixture was allowed to cool down to room temperature. The dried Novozym 435 was added, which represented the start of the reaction. During reaction, samples $(\sim 0.02 \mathrm{~mL})$ were drawn from the reaction mixture using a glass Pasteur pipette. The sample was diluted with dichloromethane and the enzyme was removed from the sample by filtration over cotton wool. The samples were analyzed by chiral GC for conversion of both enantiomers of 6-MeCL. After completion of the reaction, the enzymatic reaction was 
stopped by filtration using a class 3 glass filter and the filter was flushed with toluene. The filtrate was concentrated and the remaining 6-MeCL was removed by distillation using a Kugelrohr apparatus $\left(\mathrm{T}=80{ }^{\circ} \mathrm{C}, 0.05 \mathrm{~mm} \mathrm{Hg}\right)$. The product was used without further purification $(1.60 \mathrm{~g})$.

${ }^{1} \mathrm{H}$ NMR $\delta(\mathrm{ppm})$ 7.3-7.4 (m, Ar- $\left.H\right), 5.1\left(\mathrm{Ar}-\mathrm{CH}_{2}-\mathrm{O}\right), 4.9\left(\mathrm{~m}, \mathrm{CH}\left(\mathrm{CH}_{3}\right) \mathrm{OCOCH}_{2}\right), 3.8$ (m, $\left.\mathrm{CH}\left(\mathrm{CH}_{3}\right) \mathrm{OH}\right), 2.3\left(\mathrm{~m}, \mathrm{CH}\left(\mathrm{CH}_{3}\right) \mathrm{OCOCH}_{2}\right), 1.65-1.35\left(\mathrm{~m}, \mathrm{OCOCH}_{2}\left(\mathrm{CH}_{2}\right)_{3}\right), 1.15$ (d, $\left.\mathrm{CH}_{3}\right)$

Synthesis of 1 a using (S)-6-MeCL

Novozym $435(0.10 \mathrm{~g})$ and a magnetic stirring bar were added to a Schlenk tube. The tube was put overnight in a vacuum oven $(10 \mathrm{~mm} \mathrm{Hg})$ at $50{ }^{\circ} \mathrm{C}$ in presence of $\mathrm{P}_{2} \mathrm{O}_{5}$. The oven was backfilled with nitrogen and the tube was removed from the oven. Benzyl alcohol (0.78 g; $7.2 \mathrm{mmol}), 6-\mathrm{MeCL}$ (3.0 g; $23 \mathrm{mmol})$, 1,3,5-tri-tert-butylbenzene (0.05 $\mathrm{g} ; 0.20 \mathrm{mmol})$ and toluene $(8 \mathrm{~mL})$ were added to the tube. The mixture was stirred at 80 ${ }^{\circ} \mathrm{C}$ for 16 hours. After completion of the reaction, which was confirmed by ${ }^{1} \mathrm{H} \mathrm{NMR}$, the enzymatic reaction was stopped by filtration using a class 3 glass filter and the filter was flushed with dichloromethane. The filtrate was concentrated and the product was used without further purification $(3.49 \mathrm{~g} ; 93 \%)$.

\section{Typical procedure for the addition of $(\mathrm{S})-6-M e C L$ to racemized 1}

Novozym 435 (50 mg) was added to a $10 \mathrm{~mL}$ sample vial. The vial was put overnight in a vacuum oven $(10 \mathrm{~mm} \mathrm{Hg})$ at $50{ }^{\circ} \mathrm{C}$ in presence of $\mathrm{P}_{2} \mathrm{O}_{5}$. The oven was backfilled with nitrogen and the vial was removed from the oven. The racemized product mixture 
(1.1 g; containing $2.1 \mathrm{mmol} \mathbf{1}$, tri-tert-butylbenzene and $4.7 \mathrm{mmol}(S)-6-\mathrm{MeCL}),(S)-6$ MeCL (1.0 g; $7.8 \mathrm{mmol})$, toluene (4 mL) and dry molecular sieves (3 $\AA$ ) were added to a $50 \mathrm{~mL}$ round-bottom flask. The mixture was stirred at $45{ }^{\circ} \mathrm{C}$ for 16 hours to remove traces of water. The dried Novozym 435 was added, which represented the start of the reaction. The mixture was stirred at $80{ }^{\circ} \mathrm{C}$ for 16 hours. After completion of the reaction,

which was confirmed by ${ }^{1} \mathrm{H}$ NMR, the enzymatic reaction was stopped by filtration using a class 3 glass filter and the filter was flushed with dichloromethane. The filtrate was concentrated. The product was quantitatively obtained and used without further purification.

\section{Typical procedure for the racemization of 6-MeCL oligomers}

$\left[\mathrm{RuCl}_{2} \text { (cymene) }\right]_{2}(38 \mathrm{mg} ; 0.06 \mathrm{mmol}),(\mathrm{rac})$ - $\alpha$-methyl-phenylglycinamide (22 mg; $0.14 \mathrm{mmol}), \mathrm{K}_{2} \mathrm{CO}_{3}(0.50 \mathrm{~g} ; 3.6 \mathrm{mmol}), 5 \mathrm{~mL}$ 2-propanol $(65 \mathrm{mmol})$ and $5 \mathrm{~mL}$ toluene were added to a $25 \mathrm{~mL}$ Schlenk tube. To remove oxygen, five consecutive vacuum-argon cycles were performed. The system was stirred at $80^{\circ} \mathrm{C}$ for 1 hour.

6-MeCL oligomer (1.0 g; $1.3 \mathrm{mmol})$ was dissolved in a mixture of $0.5 \mathrm{~mL}$ toluene and $0.5 \mathrm{~mL}$ 2-propanol. The mixture was transferred into a $15 \mathrm{~mL}$ Schlenk tube. Five vacuum-argon cycles were performed to remove oxygen. $5 \mathrm{~mL}$ of the catalyst solution was filtered through a $1 \mu \mathrm{m}$ PTFE syringe filter and added to the reaction mixture. The mixture was subjected to 3 vacuum-argon cycles and stirred at $70^{\circ} \mathrm{C}$ for 16 hours. The reaction mixture was concentrated and the catalyst was removed by column chromatography over silica using dichloromethane and subsequently ethyl acetate as the eluent. Evaporation of the solvent yielded the racemized product (0.97 g; $97 \%)$. 


\section{Hydrolysis of Generation 5 6-MeCL oligomers}

$1(0.40 \mathrm{~g} ; 0.76 \mathrm{mmol})$ was dissolved in $7 \mathrm{~mL}$ toluene in a $50 \mathrm{~mL}$ round-bottom flask. 1 $\mathrm{mL} \mathrm{MeOH}$ and 2 drops of $37 \% \mathrm{v} / \mathrm{v} \mathrm{HCl}_{\mathrm{aq}}$ were added to the mixture. The mixture was stirred at reflux for 21 hours. After completion of the reaction, which was confirmed by ${ }^{1} \mathrm{H}$ NMR, an aliquot of the reaction mixture was diluted with dichloromethane and 2 drops of trifluoroacetic anhydride were added. The mixture was analyzed on chiral GC (90 ${ }^{\circ} \mathrm{C}$ isothermal, r.t. $=26.34$ and $\left.26.99 \mathrm{~min}.\right)$.

By performing the same procedure with $(S)-6-\mathrm{MeCL}$, the peak at r.t. $=26.99 \mathrm{~min}$. was identified as the $(S)$-enantiomer of the secondary alcohol formed.

\section{One-pot synthesis of 6-MeCL oligomers}

Novozym $435(25 \mathrm{mg})$ and a magnetic stirring bar were added to a Schlenk tube. The tube was put overnight in a vacuum oven $(10 \mathrm{~mm} \mathrm{Hg})$ at $50{ }^{\circ} \mathrm{C}$ in presence of $\mathrm{P}_{2} \mathrm{O}_{5}$. The oven was backfilled with nitrogen and the tube was removed from the oven.

1-Phenyl ethanol (43 mg; $0.35 \mathrm{mmol}),(S)-6-\mathrm{MeCL}(0.50 \mathrm{~g} ; 3.9 \mathrm{mmol})$, 1,3,5-tri-tertbutylbenzene $(3.4 \mathrm{mg} ; 0.014 \mathrm{mmol})$, toluene $(2 \mathrm{~mL}), 2$,4-dimethyl-3-pentanol $(0.25 \mathrm{~mL})$

and molar sieves ( $3 \AA$ ) were added to a $25 \mathrm{~mL}$ round bottom flask. The mixture was stirred at $45{ }^{\circ} \mathrm{C}$ for 16 hours to remove traces of water. The mixture was transferred into the Schlenk tube containing the enzyme. Five vacuum-argon cycles were performed to remove oxygen. 
$\left[\mathrm{RuCl}_{2} \text { (cymene) }\right]_{2}(28 \mathrm{mg} ; 0.046 \mathrm{mmol}),($ rac $)$ - $\alpha$-methyl-phenylglycinamide (22 mg; $0.13 \mathrm{mmol}), \mathrm{K}_{2} \mathrm{CO}_{3}(0.30 \mathrm{~g} ; 0.0022 \mathrm{mmol}), 2$,4-dimethyl-3-pentanol $(2.5 \mathrm{~mL})$ and toluene ( $4 \mathrm{~mL}$ ) were added to a $25 \mathrm{~mL}$ Schlenk tube. To remove oxygen, five consecutive vacuum-argon cycles were performed. The system was stirred at $80{ }^{\circ} \mathrm{C}$ for 1 hour.

The mixture was transferred into a $15 \mathrm{~mL}$ Schlenk tube. Five vacuum-argon cycles were performed to remove oxygen. $3.5 \mathrm{~mL}$ of the catalyst solution was filtered through a $1 \mu \mathrm{m}$ PTFE syringe filter and added to the reaction mixture. $1 \mathrm{~mL}$ triethylamine $(0.72 \mathrm{~g}$; $7.12 \mathrm{mmol}$ ) was added to the reaction mixture. The mixture was subjected to 3 vacuumargon cycles and stirred at $70{ }^{\circ} \mathrm{C}$ for 192 hours.

The reaction was stopped by filtration using a class 3 glass filter. The reaction mixture was concentrated in vacuo and the catalyst was removed by column chromatography over silica using dichloromethane and subsequently ethyl acetate as the eluent. Evaporation of the solvent yielded the product. 


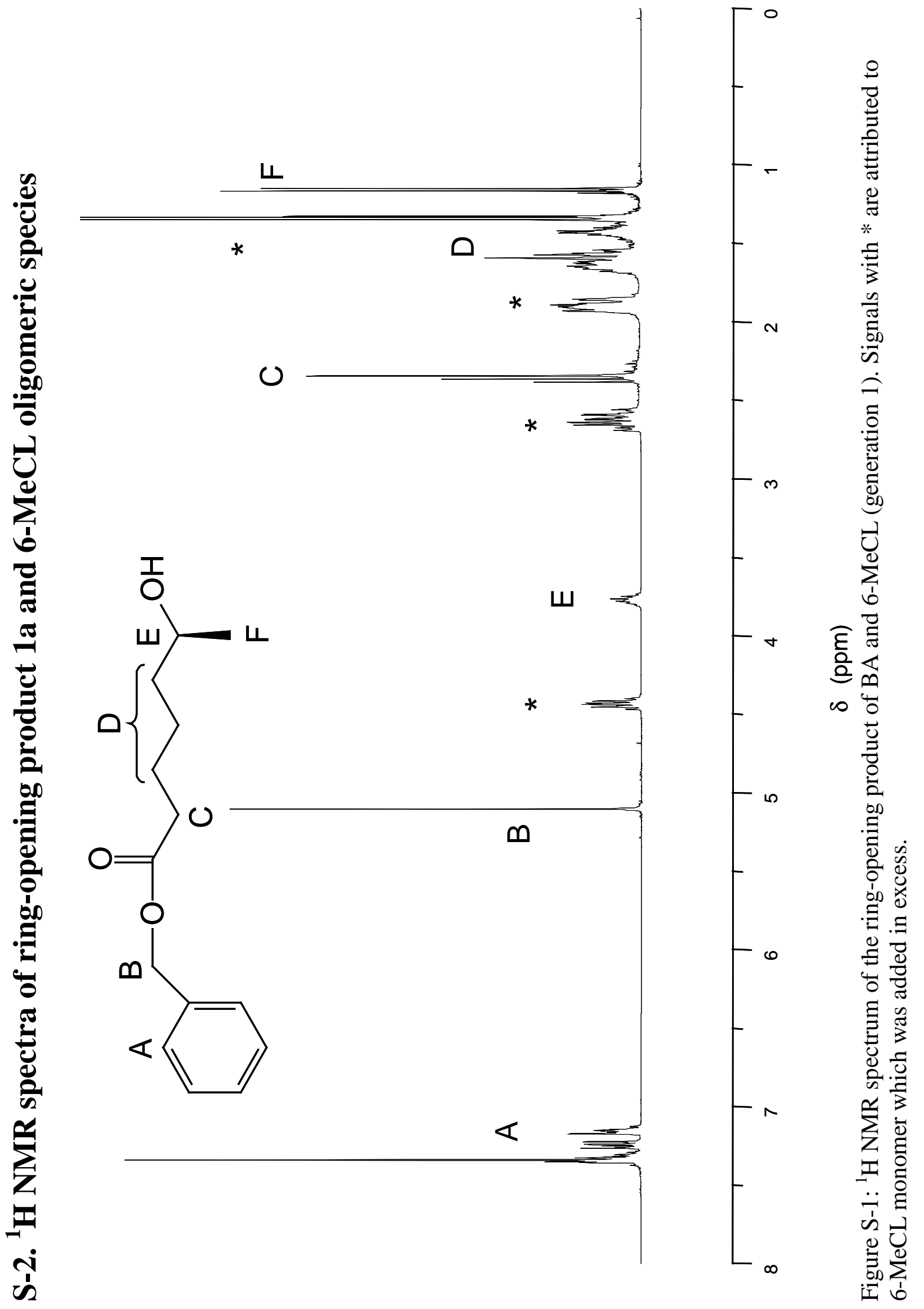


$\frac{0}{\sim}$

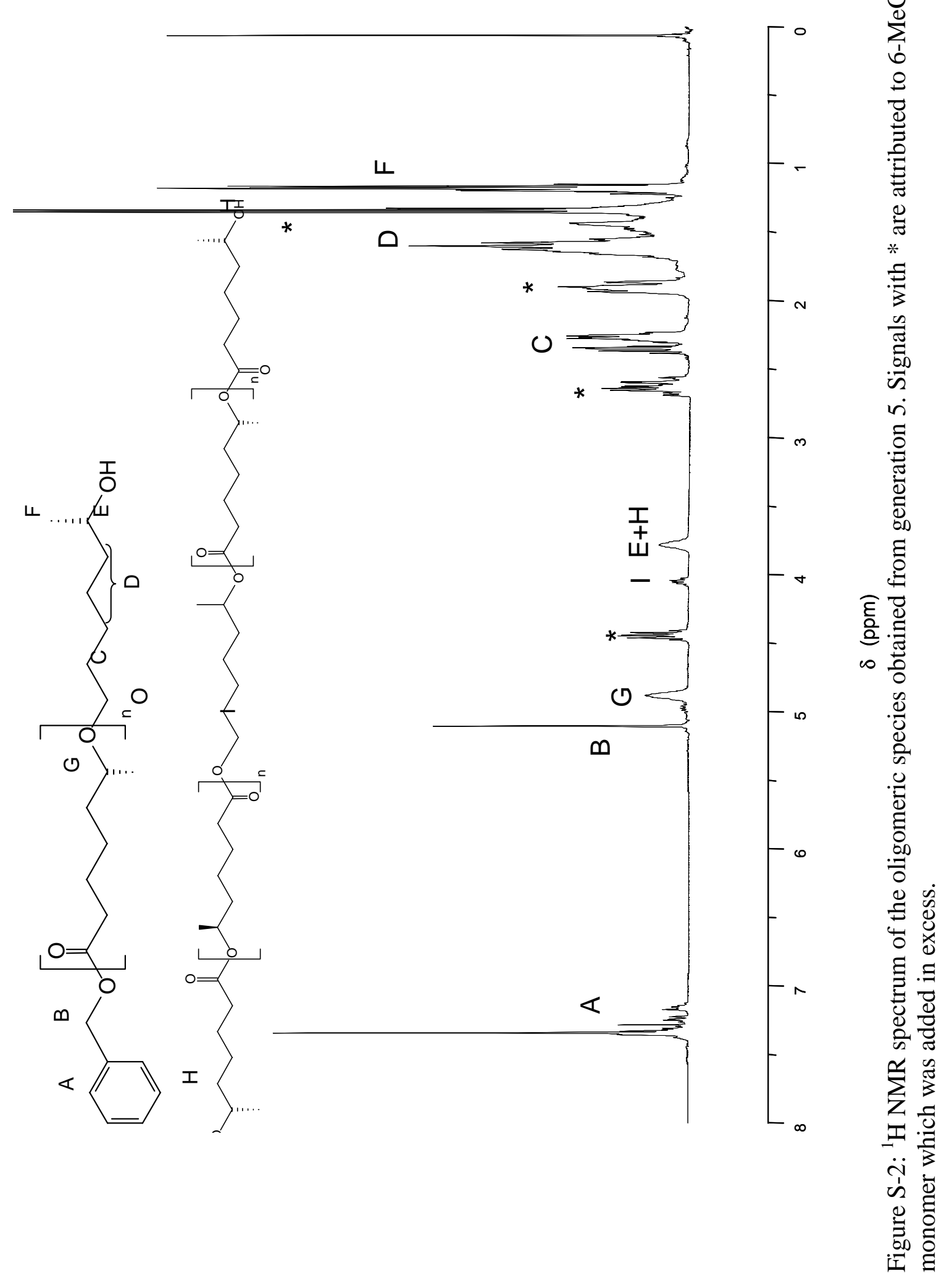



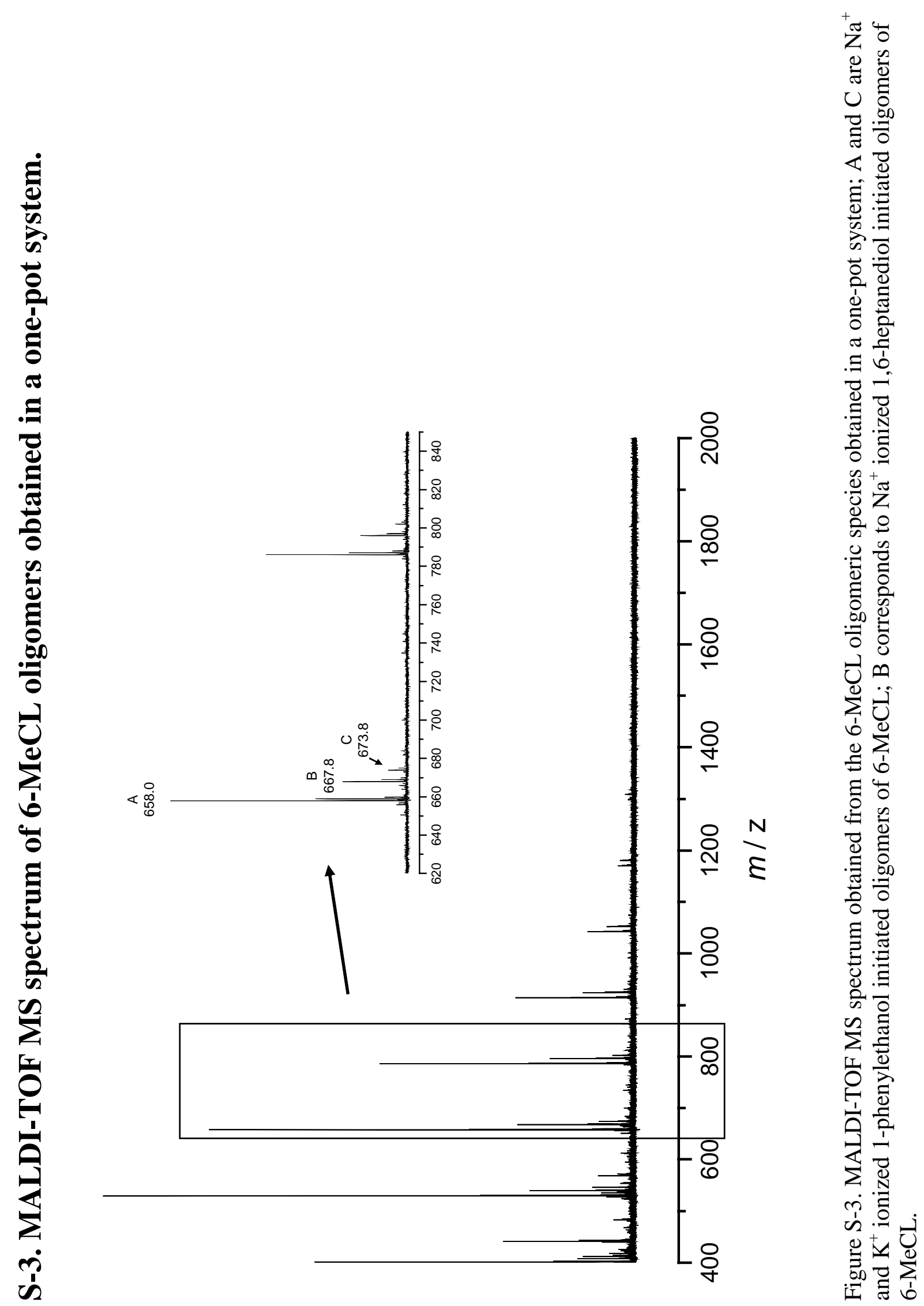